\title{
O poeta e a poesia
}

\author{
Alexandre Filordi de Carvalho
}

\section{PALAVRAS}

Insisto na letra até ela se palavrar no meu paladar. Tem vez que ela se remansa, outras tantas ela se cascata - e quase me afoga goela abaixo. Mas ao se palavrar a letra sabe-se como afagar: é lavrando o duro da ideia até os seixos hiatados rolarem em consoante ajuntamentoformando a grota do dizer, do escrever, do anunciar, ou do dito que só a gemura do silêncio comporta. Palavra assim, a gente só compreende com o estômago.

\section{O QUE E PENSAR}

Pensar como traquinas que lançam bolinhas de gude apenas para ouvir o estralo de uma na outra e, displicentemente, deixá-las caídas aonde for, se juntam-se uma na outra, ou não, vai da bola; cada qual traz a sua cor, cada qual se luciluz como se lucípeta, cada qual em sua velocidade, cada qual em seu rumo, cada qual, bolinha de gude. Pensar assim é rolar, apenas deslizar, jogar, brincar ou só, ou em dupla, ou em grupo, mas rindo, como quem ri por lançar a bolinha de gude por lançar pois no fim, pensar é isto: desgrudar do que está grudado na gente 


\section{TEOREMA}

Mata-burro também mata gente Burro não mata burro Gente mata gente Quem é o burro?

\section{SUSTANÇA}

Ciscando o chão do meu torrão cato minusculosidades: caquinho de leveza tico de cheiro de neném cadinho de pó de saudade raminho caído de bico de beija-flor lasca de sol ventinho incrustado semente de belezura cheirim de insignificância pena de asa de liberdade areinha de esquecimento e fuligem de pacholice é preciso encher a goela pra fortalecer os ócios do corpo.

\section{DESCONTRADIÇAO}

Insistência é capim que cresce no meio do rejunte de terra do paralelepípedo; sanha tem é raiz de tiririca, nunca alcança a fundura; angústia é como tartaruga virada, asseguro; o homem da cidade se acha mais esperto que inseto perseguindo em círculo a luz do poste; tem maldade que é ruidosa como a traça: só se ouve vendo, mas daí o buraco está feito; besouro que rola bosta vê propósito nisso; o grão não sabe se grão apenas se realiza; é o de dentro na instância da acolhida que soma para o guache; e há vantagem em viver por conta do ordenado?

Doutor em Filosofia pela USP, Doutor em Educação pela UNICAMP e professor de Filosofia da Educação da UNIFESP. 